\section{REVIEW PAPER}

https://doi.org/10.17059/ekon.reg.2021-3-20

UDC: 332.1 (c) BY 4.0

Natalia A. Vukovic a), Viola A. Larionova ${ }^{\text {b) }}$, Pierfrancesco Morganti ${ }^{c}$ )

a) National Research University "Higher School of Economics", Moscow, Russian Federation

b) Ural Federal University, Ekaterinburg, Russian Federation

c) Historical Museum of Sanitary Art, Rome, Italy

a) https://orcid.org/0000-0002-4593-2835, e-mail: nvukovich@hse.ru

b) https://orcid.org/0000-0002-2132-5176

c) https://orcid.org/0000-0003-2150-2491

\title{
Smart Sustainable Cities: Smart Approaches and Analysis
}

Nowadays, more than 700 smart city projects are developing worldwide. Smart-green integration in urban regions stimulates the development and implementation of the smart sustainable city (SSC) concept. The present research aims to analyse and classify modern approaches to this concept, as well as to identify which one is the most promising. Both rejecting and affirmative approaches to the topic of SSC were taken into account. We conceptually investigated and systematised modern affirmative approaches - technocentric, socio-economic, green economic and human-oriented ones. The analysed data on the smart sustainable city concept includes scientific works published and indexed in the international citation databases (Scopus and Web of Science), reports of the Organization for Economic Co-operation and Development, the United Nations General Assembly, the International Energy Agency, as well as the authors' survey results from previous research. The paper highlights the current trend of the dominance of sustainable and human-oriented approaches in the smart sustainable city concepts and the growing importance of smart urban communities. The examination of the EU case study demonstrated the important role of sustainable development and wastewater treatment in evaluating and ranking smart sustainable. The obtained results demonstrate that $75 \%$ of SSCs from the Lisbon ranking stated waste treatment as their priority. Only 7 of 28 (25\%) chosen cities did not achieve great results in this area. This fact proves the priority of waste treatment in the development of the smart sustainable city concept. The findings confirm that the research results could be implemented in smart sustainable cities around the world.

Keywords: smart city, sustainable city, smart sustainable city, sustainable development, techno-centric approach, socio-economic approach, sustainable approach, human-oriented approach, urban environment, urban communities, agglomeration, municipal economy, territorial development, regional economy

\section{Acknowledgements}

The article has been prepared in the framework of the 2021 research project «The impact of the COVID-19 pandemic on the development of the global digital economy in the renewable energy segment» of the Faculty of World Economy and World Politics of the Higher School of Economics.

For citation: Vukovic, N. A., Larionova, V. A. \& Morganti, P. (2021). Smart Sustainable Cities: Smart Approaches and Analysis. Ekonomika regiona [Economy of region], 17(3), 1004-1013, https://doi.org/10.17059/ekon.reg.2021-3-20.

${ }^{1}$ (c) Vukovic Natalia A. , Larionova Viola A., Morganti Pierfrancesco. Text. 2021 
Н. А. Вукович ${ }^{\text {a) }, \text { В. А. Ларионова б), П. Морганти }}{ }^{\text {) }}$

а) Национальный исследовательский университет «Высшая школа экономики», Москва, Российская Федерация

6) Уральский федеральный университет имени первого Президента России Б. Н. Ельцина, Екатеринбург, Российская Федерация

в) Академия истории здравоохранения, Рим, Италия a) https://orcid.org/0000-0002-4593-2835, e-mail: nvukovich@hse.ru 6) https://orcid.org/0000-0002-2132-5176

в) https://orcid.org/0000-0003-2150-2491

\section{Современные подходы к анализу устойчивости «умных» городов}

В настоящее время в мире насчитывается более 700 проектов умных городов. Интеграция «умных» и «зеленых» инициатив стимулирует развитие и внедрение конщепции «умного устойчивого города» (Smart Sustainable City). Цель настоящего исследования - анализ и классификация различных подходов $к$ данной концепции, а также выявление наиболее перспективного из них. Были концептуально систематизированы следующие современные позитивные подходы: техноцентрический, социально-экономический, экологический и ориентированный на человека. Исследование основано на анализе научных работ, посвященных «умным устойчивым городам» и проиндексированных в международных наукометрических базах данных (Scopus u Web of Science), отчетов Организации экономического сотрудничества и развития, Генеральной Ассамблеи ООН, Международного энергетического агентства, а также на более ранних работах авторов. В статье подчеркивается тенденция преобладания устойчивых и ориентированных на человека подходов в концепциях умных устойчивых городов, а также растущее значение городских сообществ. На примере Евросоюза продемонстрирована важность устойчивого развития городов и очистки сточных вод: исследование показало, что для 75 \% городов, включенных в Лиссабонский рейтинг, приоритетной задачей является переработка отходов. Только 7 из 28 (25\%) исследованных городов не достигли высоких результатов в этой области. Исходя из подобной статистики, можно утверждать, что управление отходами играет значительную роль в развитии концепции «умного устойчивого города». Результаты исследования свидетельствуют о возможности применения описанных методик в умных устойчивых городах по всему миру.

Ключевые слова: умный город, устойчивый город, умный устойчивый город, устойчивое развитие, техноцентрический подход, социально-экономический подход, устойчивый подход, ориентированный на человека подход, городская среда, городские сообщества, агломерация, муниципальная экономика, территориальное развитие, региональная экономика

\section{Благодарность}

Статья подготовлена в рамках исследовательского проекта 2021 г. «Влияние пандемии COVID-19 на развитие мировой иифровой экономики в сегменте возобновляемых источников энергии» Факультета Мировой Экономики и Мировой Политики НИУ ВШЭ.

Для цитирования: Вукович Н. А., Ларионова В. А., Морганти П. Современные подходы к анализу устойчивости «умных» городов. Экономика региона. 2021. Т. 17, вып. 3. С. 1004-1013. https://doi.org/10.17059/ekon.reg.2021-3-20.

\section{Introduction}

In the 20th century, concepts of Industry 4.0 and Society 5.0, together with the global trend of growth of urban population, initiated the development of the smart city. Currently, according to the results presented at the Smart City Expo Barcelona, 2019 ${ }^{1}$, there are more than 700 smart city projects in the world.

\footnotetext{
1 See: https://smartcities-infosystem.eu/newsroom/events/ smart-city-expo-world-congress-2019 (date of access: 20.07.2021).
}

The concept of smart city is still developing. For example, in 2006, only 13 publications on smart cities were indexed in Web of Science (WOS) and 33 in Scopus [1]. Publications on sustainable cities were much more popular: in the same year, Web of Science referenced 290 works, while Scopus indexed 333 [1]. Simultaneously, the trend of smart-green integration stimulates cooperation between these concepts. Scientists continue to develop the smart sustainable city concept globally and the number of scientific publications in this field is growing every year. Therefore, the main purpose of the article is to investigate and 
Directions of smart city development with a positive influence on sustainable cities

\begin{tabular}{|c|c|c|c|c|c|}
\hline \multirow[b]{2}{*}{$\begin{array}{c}\text { Targets of SDG } 11 \text { (United } \\
\text { Nations) }\end{array}$} & \multicolumn{5}{|c|}{ Directions of smart city development [4] } \\
\hline & 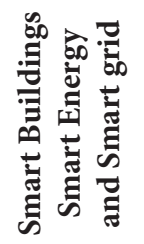 & 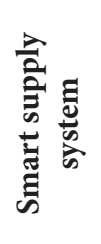 & 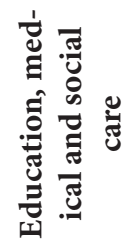 & 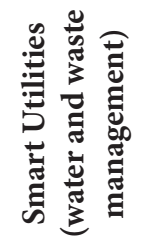 & 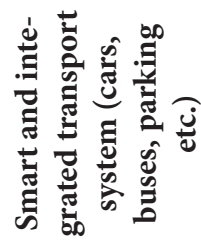 \\
\hline $\begin{array}{l}\text { Target 11.1: Safe and afforda- } \\
\text { ble housing }\end{array}$ & & & & & \\
\hline $\begin{array}{l}\text { Target 11.2: Affordable and } \\
\text { sustainable transport systems }\end{array}$ & & & & & \\
\hline $\begin{array}{l}\text { Target 11.3: Inclusive and sus- } \\
\text { tainable urbanisation }\end{array}$ & & & & & \\
\hline $\begin{array}{l}\text { Target 11.4: Protect the } \\
\text { world's cultural and natural } \\
\text { heritage }\end{array}$ & & & & & \\
\hline $\begin{array}{l}\text { Target 11.5: Reduce the ad- } \\
\text { verse effects of natural } \\
\text { disasters }\end{array}$ & & & & & \\
\hline $\begin{array}{l}\text { Target 11.6: Reduce the envi- } \\
\text { ronmental impacts of cities }\end{array}$ & & & & & \\
\hline $\begin{array}{l}\text { Target 11.7: Provide access to } \\
\text { safe and inclusive green and } \\
\text { public spaces }\end{array}$ & & & & & \\
\hline
\end{tabular}

Source: SDG Tracker. Retrieved from: https://sdg-tracker.org/cities (date of access: 20.07.2021).

analyse modern approaches to the smart sustainable city concept.

One of the first significant studies on smart sustainable cities was published by Hammer with the support of the OECD Regional Development in 2011; it was named "Cities and Green Growth: A Conceptual Framework” [2].

The first international scientific conference on smart and green urban technologies, SMARTGREENS ${ }^{1}$, the International Conference on Smart Cities and Green ICT Systems, was held in 2012. Its main aim was to unite researchers, designers, developers, and specialists interested in the advances and applications in the field of Smart Cities, Green Information and Communication Technologies, Sustainability. Additionally, one of the Conference Areas, "Energy-aware systems and technologies" focused on renewable energy sources and urban waste resources.

During its evolution, the smart city concept has been understood and analysed differently, depending on approaches and researchers. For example, Baraniewicz-Kotasińska distinguished three affirmative approaches to understanding the smart city: technocentric, socio-economic and people-oriented [3].

\footnotetext{
${ }^{1}$ See: http://www.smartgreens.org/ (date of access: 20.07.2021).
}

Popov and Semyachkov analysed the existing systematised approaches to assessing the development of smart cities and the main levels of development of smart cities [4].

The group of researchers, Boykova, Ilina and Salazkin [5], investigated the smart city approach as a response to emerging challenges for urban development. In general, many studies on this topic noted the important role of urban human capital development and smart local communities.

The density of population and global ecological challenges stimulate the implementation of sustainable development principles in modern cities, which is also true for smart city projects. One of 17 sustainable development goals (SDGs), SDG 11, is named "Sustainable cities and communities". Some smart city projects have started the process of smart-green integration, because these 2 concepts are mutually reinforcing; in many practical cases, the digital infrastructure of a smart city helps achieve all the targets set out in SDG 11.

Table 1 demonstrates the main directions of smart city development [6] and their positive influence on sustainable cities. Almost all presented directions of smart city development - smart buildings, smart energy and smart grid, smart supply system, education, medical and social care, smart utilities, and a smart and integrated trans- 
Statistics of publications in Scopus: Appearance in the title of publications, 2016-2019

\begin{tabular}{|c|l|c|c|c|c|c|}
\hline \multirow{2}{*}{ № } & \multirow{2}{*}{ Term } & \multicolumn{5}{c|}{ Number of publications by year } \\
\cline { 3 - 7 } & & $\mathbf{2 0 1 6}$ & $\mathbf{2 0 1 7}$ & $\mathbf{2 0 1 8}$ & $\mathbf{2 0 1 9}$ & $\mathbf{2 0 2 0}$ \\
\hline 1 & Smart City (SC) & 897 & 1218 & 1655 & 2021 & 1907 \\
\hline 2 & Sustainable City & 208 & 299 & 325 & 444 & 436 \\
\hline 3 & Smart Sustainable City (SSC) & 29 & 59 & 86 & 109 & 129 \\
\hline 4 & Ratio SSC/SC & $3,2 \%$ & $4,8 \%$ & $5,2 \%$ & $5,4 \%$ & $6,8 \%$ \\
\hline
\end{tabular}

Source: www.scopus.com.

port system - have a positive impact on achieving the 7 main targets of SDG 11 "Sustainable cities and communities" ${ }^{\text {. }}$

The concept of a smart sustainable city (SSC) combines elements from the smart city (SC) and the sustainable city (SuC) concepts. These concepts started to develop at the same time in 1990s. The principle of using the terms "smart" and "sustainable" in SSC is conditioned by the share of elements in this concept, and the smart city concept is dominant and determines its basis, ICT solutions. Statistics from the international scientific base Scopus demonstrate the same situation.

Table 2 shows a positive dynamic of the research numbers in the field of smart city, sustainable city, and smart sustainable city. The share of SSC publications with SC (Ratio SSC/SC) was very low (only $3 \%$ in 2016), but it has doubled in size in the last 5 years, going from $3.2 \%$ up to $6.8 \%$, even though smart sustainable city (SSC) is a relatively new term that became widespread in the 2010s. The growing number of publications on SSC confirms the increasing role of smart-green integration in the development of the smart city concept.

The aforementioned analyses results (Table 1 and Table 2) indicate that the SSC concept is connected to technological, environmental, economic, and social aspects.

In one of the recent scientific studies on SSC, Yigitcanlar et al. noted that "the findings provide evidence that the current smart city practice fails to incorporate an overarching sustainability goal that is progressive and genuine. This, then, highlights the need for a post-anthropocentric approach in practice and policymaking for the development of truly smart and sustainable cities" [7].

Leading researchers in the field of SSC Bibri and Krogstie [8, 9], who published a variety of articles on the topic, confirm that the SSC concept is in its infancy; many of its details should be investigated and designed. As a solution, they promoted an integrated approach: "...we conclude that the

\footnotetext{
${ }^{1}$ United Nations. (2017). Resolution adopted by the General Assembly on 6 July 2017, Work of the Statistical Commission pertaining to the 2030 Agenda for Sustainable Development (A/ $\mathrm{RES} / 71 / 313)$.
}

applied theoretical inquiry into smart sustainable cities of the future is deemed of high pertinence and importance, given that the research in the field is still in its early stages, and that the subject matter draws upon contemporary and influential theories with practical application... the proposed integrated approach is believed to be the first of its kind and has not been, to the best of one's knowledge, produced elsewhere" [8].

Haarstad points out the important and significant role of sustainability in the "smart city" discourse, and their correlation with each other [10].

The importance of the topic of SSC may be confirmed by the fact that the United Nations (UN) supported an initiative project, ITU-T. It is the platform for the Internet of Things (IoT) and smart sustainable cities stakeholders. The main IoT function is to exchange knowledge and identify policy and standard needs. "United for Smart Sustainable Cities" (U4SSC) is the UN initiative coordinated by the International Telecommunication Union (ITU), United Nations Economic Commission for Europe (UNECE) and UN-Habitat, and supported by other 14 UN agencies to achieve Sustainable Development Goal 11: «Make cities and human settlements inclusive, safe, resilient and sustainable» ${ }^{2}$.

The U4SSC Implementation Programme (U4SSC-IP) supports the implementation of projects and builds partnerships, which aim to create smarter and more sustainable cities worldwide.

Thus, both researchers and leading world communities recognise the smart sustainable city concept as a new and important scientific direction, which requires investigation, systematisation, and design for a global sustainable future.

\section{Methods and Theory}

To assess the development of knowledge and research on smart sustainable cities, scientific analysis of published papers, indexed in Scopus and WoS was used. This article aims to find, analyse, and systemise the theoretical knowledge on

\footnotetext{
2 See: https://www.itu.int/en/ITU-T/climatechange/resources/ Pages/Smart-sustainable-cities.aspx (date of access: 20.07.2021).
} 
Approaches to the smart sustainable city (SSC) concept

\begin{tabular}{|c|c|c|c|}
\hline № & Affirmative SSC Approaches & Key factor of the SSC development & Leading authors \\
\hline 1 & Technocentric approach & $\begin{array}{l}\text { ICT solutions for sustainable } \\
\text { development }\end{array}$ & Aina [13], Darmawan et al. [14] \\
\hline 2 & Socio-economic approach & Smart \& green entrepreneurship & Viitanen and Kingston [15] \\
\hline 3 & $\begin{array}{l}\text { Green economy } \\
\text { (Eco-socio-economic) } \\
\text { approach }\end{array}$ & New smart \& green industries & Akande et al. [16] \\
\hline 4 & $\begin{array}{l}\text { Human (People)-oriented } \\
\text { approach }\end{array}$ & $\begin{array}{l}\text { New smart \& green } \\
\text { Communities }\end{array}$ & $\begin{array}{l}\text { Bouzguenda, Alalouch and Fava [17], } \\
\text { Bednarska-Olejniczak, Olejniczak and } \\
\text { Svobodová [18], Ivaldi et al. [19], Kuzior and } \\
\text { Kuzior [20] }\end{array}$ \\
\hline
\end{tabular}

Source: Authors' elaboration.

the SSC concept and propose a classification of the existing approaches.

While conducting a critical analysis of the relevant literature, Scopus collections were searched using the terms "smart city", "sustainable city" and "smart sustainable city"; therefore, they had to be included in the in-depth analysis of the scientific landscape of SSC.

The sources for the analysis were selected according to the following criteria: relevance to topic, impact factor of the journal, number of article citations, and the publishing date (starting in 2017).

The quantitative, factor, and quality analysis of statistics were used in the research. The examined sources include reports of the Organization for Economic Co-operation and Development (OECD), the UN General Assembly, Eurostat, International Energy Agency, as well as the authors' survey results from 2019, conducted in Moscow, Saint Petersburg and Ekaterinburg in the case study analysis of the development of smart and green city concept in Russia.

\section{Hypotheses}

Hypothesis 1. The most promising approach to understanding the concept of smart sustainable city is based on human-oriented principles.

Hypothesis 2. Waste management is a key-element of the development of smart sustainable cities.

\section{Analysis}

There are various scientific approaches to the smart sustainable city concept due to its novelty. Bibri and Krogstie [8, 9, 11, 12] in their studies pointed out that "...essentially, there are multiple visions of, and pathways to achieving, smart sustainable cities based on how they can be conceptualised" [12].
Different authors involved in the analysis of SSC take into account both rejecting and affirmative approaches to the topic. They investigated and defined such main modern affirmative approaches as technocentric, socio-economic, eco-socio-economic (sustainable), and human-oriented approaches presented in Table 3.

All approaches to the SSC concept have their supporters. We can see from the systematisation results presented in Table 3 that the most popular approach is based on people-oriented principles (the human-oriented approach) [17-19].

This approach draws on the idea that smart citizens and their communities are the main drivers of urban and smart sustainable development. International practice provides a lot of evidence for proving this: a smart society can deeply and positively change the model of city development, like in Helsinki, Copenhagen, Tallinn and many other big and small cities in the world.

The dynamics of SSC scientific approaches presented in Figure 1 demonstrate a growth from ICT solutions to the principles of sustainable development.

Nowadays, there exist 2 main approaches to SSC, based on the green economy and human-oriented principles. Such approaches are characterised by the presence of common social aspects connected with urban communities; thus, in our opinion, in the future they will develop in tandem.

The driving function of urban societies in the development of smart sustainable cities is confirmed by the results of the survey, which we conducted in Russia in 2019 (Table 4). More than 496 city residents of 3 top cities by population, participated in the conducted survey (Table 4).

The surveyed citizens chose local social communities as the second main driver for the development of green and smart cities, the main driver being financial resources. Table 5 shows that $42 \%$ of participants in Ekaterinburg, $39 \%$ in Moscow 
"SSC in Russia-2019" survey characteristics

\begin{tabular}{|l|c|c|c|}
\hline \multirow{2}{*}{\multicolumn{1}{c|}{ Characteristics }} & \multicolumn{2}{c|}{ Cities } \\
\cline { 2 - 4 } & Moscow & Saint-Petersburg & Ekaterinburg \\
\hline Population 2019 & 12615882 & 5383968 & 1493749 \\
\hline Survey participants & 266 & 107 & 123 \\
\hline
\end{tabular}

Source: Authors' elaboration.

Table 5

Survey "SSC in Russia-2019" results from the question "What is the main source for the development of green and smart cities?"

\begin{tabular}{|c|l|c|c|c|}
\hline \multirow{2}{*}{ № } & \multicolumn{2}{|c|}{ Survey Questions } & \multicolumn{3}{c|}{ Cities } \\
\cline { 3 - 4 } & & Moscow & Saint Petersburg & Ekaterinburg \\
\hline 1 & Financial resource & $42.4 \%$ & $50.0 \%$ & $41.1 \%$ \\
\hline 2 & Local social communities & $39.0 \%$ & $28.3 \%$ & $42.3 \%$ \\
\hline 3 & Local business community & $9.3 \%$ & $7.5 \%$ & $15.3 \%$ \\
\hline
\end{tabular}

Source: Authors' elaboration.

Survey "SSC in Russia-2019" results from the question "What do you think is the most important in smart city solutions?"

\begin{tabular}{|c|l|c|c|c|c|}
\hline \multirow{2}{*}{ № } & \multicolumn{1}{|c|}{ Survey Questions } & Targets of SDG & \multicolumn{3}{c|}{ Cities } \\
\cline { 4 - 6 } & \multicolumn{1}{|c|}{$\begin{array}{c}\text { T1 } \\
1\end{array}$} & Smart Waste Management 11.6 & $39.40 \%$ & $37.40 \%$ & $35.10 \%$ \\
\hline 2 & $\begin{array}{l}\text { Green urban infrastructure (parks, } \\
\text { gardens and green courtyards) }\end{array}$ & Target 11.7 & $24.50 \%$ & $28.00 \%$ & $37.30 \%$ \\
\hline 3 & $\begin{array}{l}\text { Comfortable and environmentally } \\
\text { friendly public transport }\end{array}$ & Target 11.2 & $21.30 \%$ & $27.10 \%$ & $31.50 \%$ \\
\hline 4 & $\begin{array}{l}\text { Affordable and comfortable } \\
\text { electronic municipal services }\end{array}$ & Target 11.3 & $14.90 \%$ & $7.50 \%$ & $21 \%$ \\
\hline
\end{tabular}

Source: Authors' elaboration.

and $28 \%$ in Saint-Petersburg selected "Local social communities" as the driver for the development of green and smart cities.

The second significant question of the SSC survey was related to the most important solutions in smart cities. Table 6 presents the answers from residents of Moscow, Saint Petersburg, and Ekaterinburg; it is evident that smart waste man- agement is the highest priority in people's opinion: it was chosen by $39 \%$ of respondents in Moscow , $37 \%$ in Saint Petersburg and $35 \%$ in Ekaterinburg.

According to citizens opinion, green zones (Target 11.7, SDG 11) and smart transport (Target 11.2, SDG 11) were also high on the list of priorities. This case confirms the high importance of

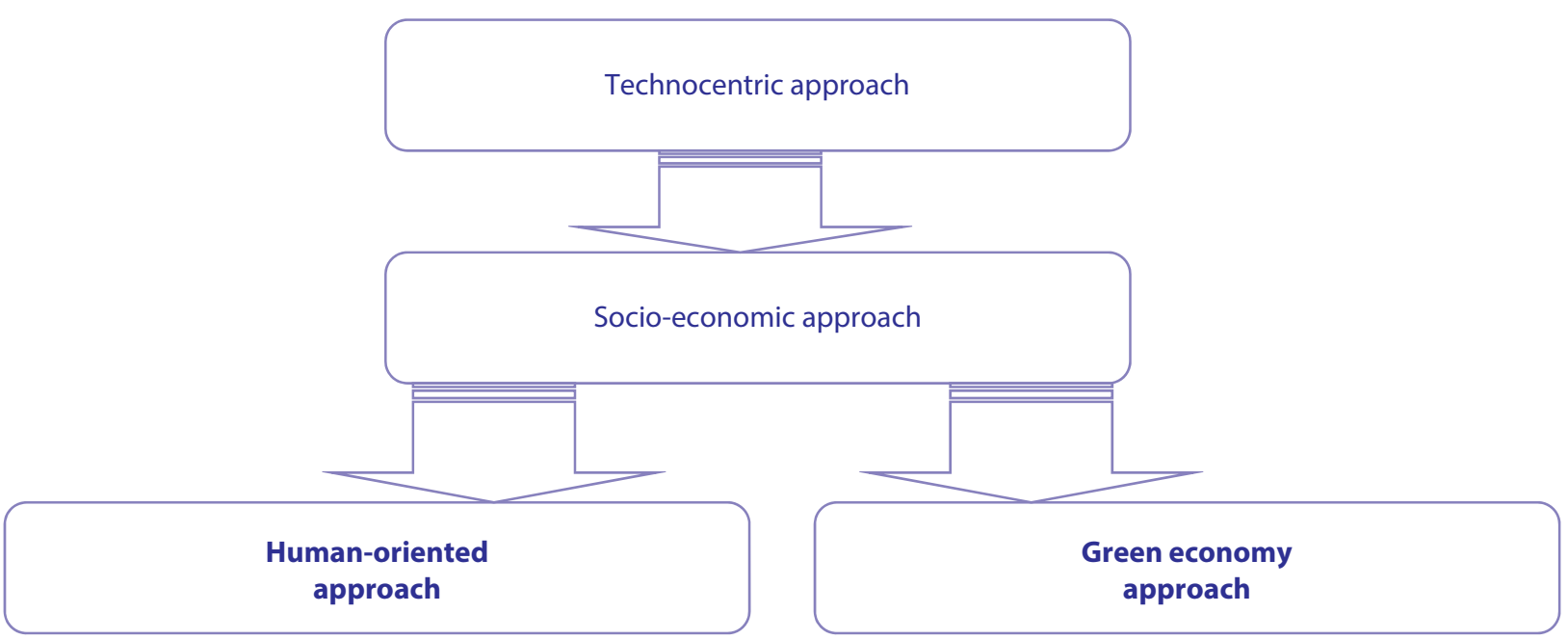

Fig. 1. Development of approaches to smart sustainable city (SSC) 


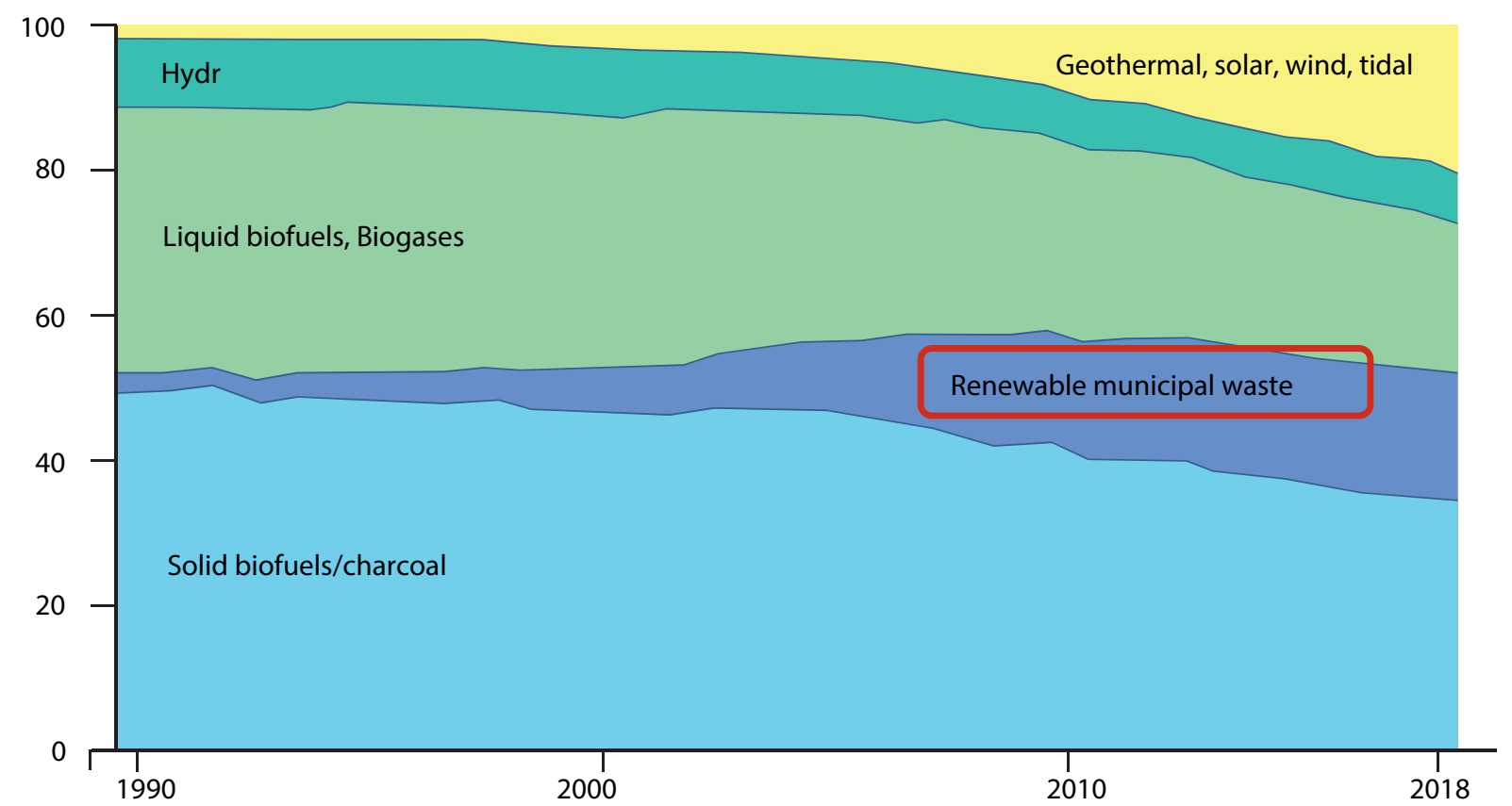

Fig. 2. OECD renewable primary energy supply by-product, 1990-2019

Source: International Energy Agency. Retrieved from: https://www.iea.org/(date of access: 20.07.2021) (IEA Report. OECD renewable primary energy supply by product, 1990-2019. Retrieved from: https://www.iea.org/data-and-statistics/charts/oecd-renewable-primary-energy-supply-by-product-1990-2019 (date of access: 20.07.2021))

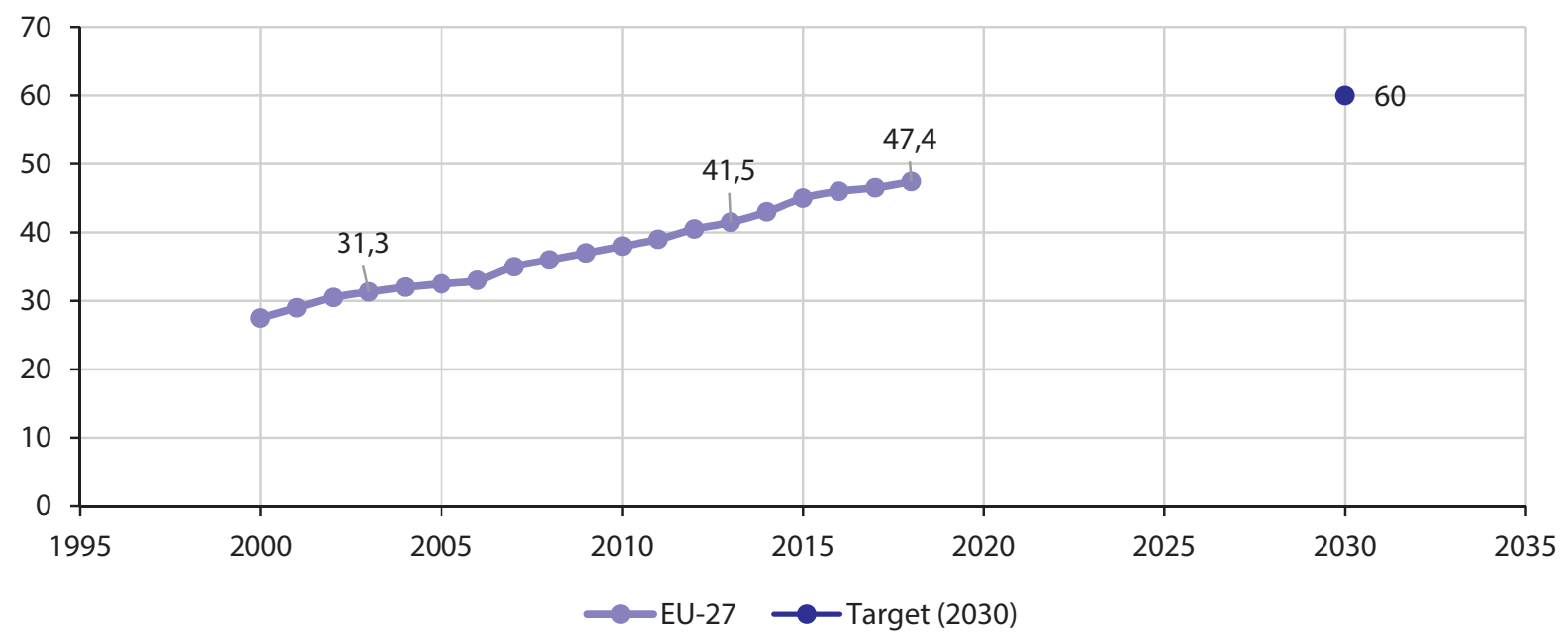

Fig. 3. Recycling rate of municipal waste, EU-27, 2000-2018(\% of total waste generated) Source: Eurostat (online data code:sdg_11_60) (Eurostat. (2020). Sustainable development in the European Union: Monitoring report on progress towards the SDGS in an EU context. Publications Office of the European Union. Retrieved from: https://ec.europa. eu/eurostat/documents/4031688/11010788/KS-01-20-192-EN-N.pdf/ae63affO-a6f3-1d47-da83-c6886b9daaab (date of access: 20.07.2021)) [22]

green and smart waste management. Global issue of quickly growing urban population and the subsequent problem of waste recycling and energy supply were replaced by waste management at the top in the concept of smart sustainable city.

Figure 2 shows OECD renewable primary energy supply by-product during 1990-2019, as well as the growing share of renewable municipal waste.

The most successful global case in recycling of municipal waste was noted in the European Union (EU). Figure 3 shows a dynamic recycling rate of municipal waste in the EU-27 during 2000-2018: the EU recycled more than $47 \%$ of urban waste; the Union's goal for 2030 is $60 \%$ of total waste generated (a very high rate).

The EU presented an interesting case of ranking smart sustainable cities. The study found common features in the green economy and human-oriented affirmative approaches for ranking the EU smart sustainable cities. This methodology, called the Lisbon ranking, was implemented to assess 28 smart sustainable cities in Europe [16].

"The methodology of Lisbon ranking is not complicated for application and gives more oppor- 
The Lisbon ranking 2019 of smart sustainable cities in Europe

\begin{tabular}{|c|c|c|c|}
\hline Rank & City & Top three indicators affecting ranking & $\begin{array}{c}\text { Waste management } \\
\text { priority }\end{array}$ \\
\hline 1 & Berlin & Bicycle network, Wastewater treatment, E-commerce & + \\
\hline 2 & Stockholm & Wastewater treatment, Patent applications, E-commerce & + \\
\hline 3 & Helsinki & Wastewater treatment, Patent applications, Bicycle network & + \\
\hline 4 & London & Wastewater treatment, Bicycle network, E-commerce & + \\
\hline 5 & Copenhagen & Wastewater treatment, E-commerce, Patent applications & + \\
\hline 6 & Paris & Wastewater treatment, Unemployment, GHG emissions & + \\
\hline 7 & Amsterdam & Wastewater treatment, E-Commerce, Unemployment & + \\
\hline 8 & Prague & Wastewater treatment, E-Commerce, Gender inequality & + \\
\hline 9 & Vienna & Gender Inequality, Patent applications, E-Commerce & - \\
\hline 10 & Dublin & E-Commerce, Wastewater treatment, Unemployment & + \\
\hline 11 & Tallinn & Wastewater treatment, Gender Inequality, Unemployment & + \\
\hline 12 & Brussels & E-Commerce, Wastewater treatment, Patent application & + \\
\hline 13 & Madrid & Wastewater treatment, Protected terrestrial area, E-Commerce & + \\
\hline 14 & Lisbon & Wastewater treatment, Unemployment, E-Commerce & + \\
\hline 15 & Luxembourg & Wastewater treatment, Protected terrestrial area, Unemployment & + \\
\hline 16 & Valletta & Wastewater treatment, PM10 concentration, E-commerce & + \\
\hline 17 & Riga & Wastewater treatment, Unemployment, Gender inequality & + \\
\hline 18 & Budapest & Wastewater treatment, Unemployment, Protected terrestrial area & + \\
\hline 19 & Vilnius & Unemployment, E-commerce, Gender inequality & - \\
\hline 20 & Warsaw & Wastewater treatment, PM10 concentration, Protected terrestrial area & + \\
\hline 21 & Rome & GHG emissions, Protected terrestrial area, PM10 concentration & - \\
\hline 22 & Bratislava & Protected terrestrial area, Gender inequality, E-commerce & - \\
\hline 23 & Zagreb & Protected terrestrial area, E-commerce, Unemployment & - \\
\hline 24 & Ljubljana & Protected terrestrial area, E-commerce, Wastewater treatment & + \\
\hline 25 & Nicosia & Protected terrestrial area, PM10 concentration, Unemployment & - \\
\hline 26 & Athens & Protected terrestrial area, Wastewater treatment, PM10 concentration & + \\
\hline 27 & Bucharest & PM10 concentration, Wastewater treatment, Protected terrestrial area & + \\
\hline 28 & Sofia & PM10 concentration, Protected terrestrial area, Unemployment & - \\
\hline
\end{tabular}

Source: [16].

tunities than many other ranking systems, which may be stronger by methodological part, but not applicable in practice, because of a deficit of data for analyses" [16].

For example, the "United for Smart Sustainable Cities" (U4SSC) ${ }^{1}$ is a "UN initiative coordinated by ITU, UNECE and UN-Habitat, and developed a set of international key performance indicators (KPIs) for Smart Sustainable Cities (SSC) to establish the criteria to evaluate ICT's contributions in making cities smarter and more sustainable, and to provide cities with the means for self-assessments in order to achieve the sustainable development goals (SDGs)" 7 .

The two-pronged approach includes the feature selection to obtain a smaller number of variables to represent the larger group of 32 variables, and then feature extraction to build a new set of

\footnotetext{
1 See: https://www.itu.int/en/ITU-T/climatechange/resources/ Pages/Smart-sustainable-cities.aspx (date of access: 20.07.2021).
}

variables while reducing noise and redundancy in the process. Globally, only 100 cities worldwide are already implementing these KPIs (Moscow, Valencia, etc.). Implementation of the smart city technologies in environmental protection proves its efficiency in the case studies in Russia and Kazakhstan [21].

Many methodologies are still in the process of development and improvement; smart sustainable city roadmaps by Ibrahim, El-Zaart and Adams [22]; indicators for assessing smart and sustainable cities' and communities' performance by Stratigea, Leka \& Panagiotopoulou [23]; indicators and assessment tools for smart sustainable cities by Garau and Pavan [24]; indicators and standards of smart sustainable cities by Huovila, Bosch and Airaksinen [25]. However, it is possible to use inly some of them due to the limitations of the urban data set.

The advantage of the Lisbon ranking 2019 is its applicability. Results of the EU city ranking 
by smart sustainable city methodology are presented in Table 7. It can be concluded that $75 \%$ of SSCs from the Lisbon ranking stated waste treatment as their priority. Only 7 of 28 (25\%) chosen smart sustainable cities did not achieve great results in waste treatment. This fact proves the importance of waste treatment in the development of the smart sustainable city concept.

\section{Results and Discussion}

The research results of literature analyses and the systematisation of modern approaches to smart sustainable cities proves the hypothesis that this is a promising concept of urban development. The most prospective approaches are based on the principles of smart-green integration.

Additionally, the analyses of scientific publications concerning the SSC clarified the common features of many modern approaches. This can be explained by the evidence that human resources are the main asset of smart and sustainable cities because people and communities are the main urban stakeholders, beneficiaries, and drivers of city development.

The analysis of modern rankings of smart sustainable cities indicates that green waste treatment (management) is the key element in the development of the top smart sustainable cities in the EU, based on the Lisbon ranking of 2019. Thus, this approach could be suitable for other countries due to the global challenge of urban waste management.

The findings confirm that the research results could be implemented around the world to design smart sustainable cities and construct theoretical approaches to understanding these concepts.

The Covid-19 pandemic of 2020 and 2021 proves the efficiency of the smart city concept, because such cities navigated the pandemic more effectively than others did. The smart city could be efficiently used to develop urban health and sustainable city concepts in the future.

\section{References}

1. Janik, A., Ryszko, A. \& Szafraniec, M. (2020). Scientific landscape of smart and sustainable cities literature: A bibliometric analysis. Sustainability, 12(3), 779. DOI: https://doi.org/10.3390/su12030779.

2. Hammer, S., Kamal-Chaoui, L., Robert, A. \& Plouin, M. (2011). Cities and Green Growth: A Conceptual Framework. OECD Regional Development Working Papers 2011/08, OECD Publishing. DOI: 10.1787/5kg0tflmzx34-en.

3. Baraniewicz-Kotasińska, S. (2020). Smart city. Four approaches to the concept of understanding. Urban Research \& Practice, 1-24. DOI: 10.1080/17535069.2020.1818817.

4. Popov, E. V. \& Semyachkov, K. A. (2020). Systematisation of Approaches to Assessing the Development of Smart Cities. Ekonomika regiona [Economy of region], 16(1), 14-27. DOI: 10.17059/2020-1-2 (In Russ.)

5. Boykova, M., Ilina, I. \& Salazkin, M. (2016). The Smart City approach as a response to emerging challenges for urban development. Forsayt [Foresight and STI Governance], 10(3), 65-75. DOI:10.17323/1995-459X.2016.3.65.75.

6. Eremia, M., Toma, L. \& Sanduleac, M. (2017). The Smart City Concept in the 21st Century. Procedia Engineering, 181, 12-19. DOI: 10.1016/j.proeng.2017.02.357.

7. Yigitcanlar, T., Kamruzzaman, M., Foth, M., Sabatini, J., da Costa, E. \& Ioppolo, G. (2018). Can cities become smart without being sustainable? A systematic review of the literature. Sustainable Cities and Society, 45, 348-365. DOI: 10.1016/j. scs.2018.11.033.

8. Bibri, S. E., \& Krogstie, J. (2017). Smart sustainable cities of the future: An extensive interdisciplinary literature review. Sustainable Cities and Society, 31, 183-212. DOI: 10.1016/j.scs.2017.02.016.

9. Bibri, S. E. (2018). Backcasting in futures studies: a synthesized scholarly and planning approach to strategic smart sustainable city development. European Journal of Futures Research, 6(1), 1-27. DOI: 10.1186/s40309-018-0142-z.

10. Haarstad, H. (2016). Constructing the sustainable city: examining the role of sustainability in the "smart city" discourse. Journal of Environmental Policy \& Planning, 19(4), 423-437. DOI: 10.1080/1523908X.2016.1245610.

11. Bibri, S. E. (2018). A foundational framework for smart sustainable city development: Theoretical, disciplinary, and discursive dimensions and their synergies. Sustainable Cities and Society, 38, 758-794. DOI: 10.1016/j.scs.2017.12.032.

12. Bibri, S. E. \& Krogstie, J. (2019). Generating a vision for smart sustainable cities of the future: a scholarly backcasting approach. European Journal of Futures Research, 7(1), 1-20. DOI: 10.1186/s40309-019-0157-0.

13. Aina, Y. A. (2017). Achieving smart sustainable cities with GeoICT support: The Saudi evolving smart cities. Cities, 71, 49-58. DOI: 10.1016/j.cities.2017.07.007.

14. Darmawan, A. K., Siahaan, D. O., Susanto, T. D., Hoiriyah, Umam, B. A. \& Bakir, B. (2020). Exploring Factors Influencing Smart Sustainable City Adoption using E-Government Services Effectiveness Evaluation Framework (E-GEEF). In: $20203 r$ International Conference on Information and Communications Technology (ICOIACT) (pp. 234-239). IEEE. DOI: 10.1109/ICOIACT50329.2020.9332140.

15. Viitanen, J. \& Kingston, R. (2014). Smart cities and green growth: outsourcing democratic and environmental resilience to the global technology sector. Environment and Planning A, 46(4), 803-819. DOI: 10.1068/a46242.

16. Akande, A., Cabral, P., Gomes, P. \& Casteleyn, S. (2019). The Lisbon ranking for smart sustainable cities in Europe. Sustainable Cities and Society, 44, 475-487. DOI: 10.1016/j.scs.2018.10.009. 
17. Bouzguenda, I., Alalouch, C. \& Fava, N. (2019). Towards smart sustainable cities: A review of the role digital citizen participation could play in advancing social sustainability. Sustainable Cities and Society, 50, 101627. DOI: 10.1016/j. scs.2019.101627.

18. Bednarska-Olejniczak, D., Olejniczak, J. \& Svobodová, L. (2019). Towards a smart and sustainable city with the involvement of public participation-The case of Wroclaw. Sustainability, 11(2), 332. DOI: 10.3390/su11020332.

19. Ivaldi, E., Penco, L., Isola, G. \& Musso, E. (2020). Smart Sustainable Cities and the Urban Knowledge-Based Economy: A NUTS3 Level Analysis. Social Indicators Research, 150(1), 45-72. DOI: 10.1007/s11205-020-02292-0.

20. Kuzior, A. \& Kuzior, P. (2020). The quadruple helix model as a smart city design principle. Virtual Economics, 3(1), 39-57. DOI: 10.34021/ve.2020.03.01.

21. Turgel, I., Bozhko, L., Ulyanova, E. \& Khabdullin, A. (2019). Implementation of the Smart City Technology for Environmental Protection Management of Cities: The Experience of Russia and Kazakhstan. Environmental and Climate Technologies, 23(2), 148-165. DOI: 10.2478/rtuect-2019-0061.

22. Ibrahim, M., El-Zaart, A. \& Adams, C. (2018). Smart sustainable cities roadmap: Readiness for transformation towards urban sustainability. Sustainable cities and society, 37, 530-540. DOI: https://doi.org/10.1016/j.scs.2017.10.008.

23. Stratigea, A., Leka, A. \& Panagiotopoulou, M. (2019). In search of indicators for assessing smart and sustainable cities and communities' performance. In: Smart Cities and Smart Spaces: Concepts, Methodologies, Tools, and Applications (pp. 265-295). IGI Global. DOI: 10.4018/978-1-5225-7030-1.ch012.

24. Garau, C. \& Pavan, V. M. (2018). Evaluating urban quality: Indicators and assessment tools for smart sustainable cities. Sustainability, 10(3), 575. DOI: 10.3390/su10030575.

25. Huovila, A., Bosch, P. \& Airaksinen, M. (2019). Comparative analysis of standardized indicators for Smart sustainable cities: What indicators and standards to use and when? Cities, 89, 141-153. DOI: 10.1016/j.cities.2019.01.029.

\section{About the authors}

Natalia A. Vukovic - Cand. Sci. (Econ.), Associate Professor, Department of World Economy, Faculty of World Economy and International Affairs, National Research University "Higher School of Economics"; Scopus Author ID: 57110136500; https://orcid.org/0000-0002-4593-2835 (7, Malaya Ordynka St., Moscow, 115184, Russian Federation; e-mail: nvukovich@ hse.ru).

Viola A. Larionova - Cand. Sci. (Phys.-Math.), Associate Professor, Graduate School of Economics and Management, Ural Federal University; Scopus Author ID: 7003983235; https://orcid.org/0000-0002-2132-5176 (19, Mira St., Ekaterinburg, 620002, Russian Federation; e-mail: v.a.larionova@urfu.ru).

Pierfrancesco Morganti - PhD, Full Professor, Historical Museum of Sanitary Art; Scopus Author ID: 7005392688; https:// https://orcid.org/0000-0003-2150-2491 (3, Lungotevere in Sassia, Rome, 00186, Italy; e-mail: pierfrancesco.morganti@iscd.it).

\section{Информация об авторах}

Вукович Наталья Анатольевна - кандидат экономических наук, доцент, Департамент мировой экономики, Факультет мировой экономики и мировой политики, Национальный исследовательский университет «Высшая школа экономики»; Scopus Author ID: 57110136500; https://orcid.org/0000-0002-4593-2835 (Российская Федерация, 115184, г. Москва, ул. Малая Ордынка, д. 7; e-mail: nvukovich@hse.ru).

Ларионова Виола Анатольевна - кандидат физико-математических наук, доцент, Институт экономики и управления, Уральский федеральный университет имени первого Президента России Б. Н. Ельцина; Scopus Author ID: 7003983235; https://orcid.org/0000-0002-2132-5176 (Российская Федерация, 620002, г. Екатеринбург, ул. Мира, 19; e-mail: v.a.larionova@urfu.ru).

Морганти Пьерфранческо - PhD, профессор, Академия истории здравоохранения; Scopus Author ID: 7005392688; https://orcid.org/0000-0003-2150-2491 (Италия, 00186, г. Рим, Набережная Сассии, 3; e-mail: pierfrancesco. morganti@iscd.it).

Дата поступления рукописи: 26.02.2021

Прошла рецензирование: 06.04.2021

Принято решение о публикации: 18.06.2021.

Received: 26 Feb 2021.

Reviewed: 6 Apr 2021.

Accepted: 18 Jun 2021. 